\title{
When the Death Penalty Goes Public: Referendum, Initiative, and the Fate of Capital Punishment
}

\author{
Austin Sarat, John Malague, Lakeisha Arias de los Santos, Katherine Pedersen, \\ Noor Qasim, Logan Seymour, and Sarah Wishloff
}

This article considers what happens when the death penalty is put on the ballot. It reviews the history of referenda/initiatives concerning capital punishment from the start of the twentieth century to the present. That history reveals the role that referendal initiatives have played in struggles against and within governmental institutions. In addition, we find that abolitionists seldom prevail in those electoral contests. We consider the implications of these findings for the prospects that the death penalty could be ended democratically.

\section{INTRODUCTION}

The year 2016 was not a good one for opponents of capital punishment in the United States. Their cause suffered an important setback when Donald Trump, an avid death penalty supporter, was elected president (Clark 2017). With Trump's election, and his choice of Jeff Sessions as Attorney General, hope for continued restraint in the pursuit of federal death penalty cases and for the appointment of a Supreme Court justice sympathetic to the anti-death-penalty cause was dashed (Donohue and Schoening 2017).

In addition, voters in several states made known their support for capital punishment (Owens 2016). In California, which has more than seven-hundred death row inmates (St. John and Moore 2016), voters approved Proposition 66. This ballot measure promises to speed up the death penalty process by designating special courts to hear challenges to death penalty convictions. It also limits successive appeals and expands the pool of lawyers who could handle those appeals

Austin Sarat is Associate Dean of the Faculty and William Nelson Cromwell Professor of Jurisprudence and Political Science at Amherst College. He can be reached at adsarat@amherst.edu.

John Malague is a student at Amherst College majoring in law, jurisprudence, and social thought.

Lakeisha Arias de los Santos is a student at Amherst College majoring in political science.

Katherine Pedersen is a student at Amherst College majoring in French and political science.

Noor Qasim is a student at Amherst College majoring in English.

Logan Seymour is a student at Amherst College majoring in law, jurisprudence, and social thought.

Sarah Wishloff is a student at Amherst College majoring in anthropology.

We are grateful for the indispensable assistance of Missy Roser, Head of Research and Instruction, at the Amherst College Library and to the Mellon Foundation, whose financial support made our collaboration possible. 
(Ballotpedia n.d.c). ${ }^{1}$ At the same time, California voters also defeated Proposition 62 , a measure that would have ended the death penalty and replaced it with life in prison without parole (Ballotpedia n.d.b).

As notable as were the results in California, ballot measures in Oklahoma and Nebraska added to abolitionists' woes. Two-thirds of Oklahoma voters supported State Question 776 (Tulsa World 2016), which declared that the death penalty cannot be considered cruel and unusual under the state constitution. It also included a provision that "any method of execution shall be allowed, unless prohibited by the United States Constitution." It thus opened the way for Oklahoma to employ the gas chamber, electrocution, or firing squad if lethal injection is declared unconstitutional or is "otherwise unavailable" (Ballotpedia n.d.e). Finally, the Nebraska electorate, by a margin of 61 percent to 39 percent, reinstated the death penalty just one year after state legislators voted to abolish it (Hammel 2016). The results in these elections seemed to put a brake on two decades of accelerating momentum toward ending the death penalty (Toobin 2016).

The ballot measures in California, Oklahoma, and Nebraska exemplify what James Whitman $(2003,13)$ calls the "weakness" of the US state in comparison with nations like France and Germany. Strong states are both "relatively powerful and autonomous.... They are autonomous in the sense that they are steered by bureaucracies that are relatively immune from the vagaries of public opinion" (Whitman 2003, 13-14). In contrast, America's political system divides and fragments power and, through the use of initiative and referendum, offers opportunities for the public to override the decisions of state officials and political elites (Whitman 2003, 13). The vulnerability of the state, Whitman argues, is particularly consequential in the domain of crime and punishment, where the public tends to be more punitive in its dispositions than state officials and elites (Whitman 2003, 14).

The strength of the state allowed European nations to abolish capital punishment even when a majority of their citizens continued to support it (Zimring and Hawkins 1986). At the same time, however, support for the death penalty in Europe has declined over time as the public has adjusted to living without capital punishment (BBC 2015). Describing European abolition, Whitman (2003, 200-01) observes that "government actors initiate abolition and slowly bring public opinion around."

The death penalty persists in the United States in large part because lawmakers responsible for criminal justice policy are much more responsive to the public than are their counterparts in Europe. What sets America apart, Whitman argues, "is the relatively easy translation of majority sentiment into policy" (Whitman 2003, 200). Even when courts, legislators, or executives have been willing to face the political consequences of trying to abolish the death penalty, direct legislation has enabled the public to parry those efforts.

This article puts the 2016 electoral results in a broad historical context and highlights the question of whether ending the death penalty can be done democratically. It describes changes in the uses of initiative and referendum processes to

1. The California Supreme Court recently upheld Proposition 66, resisting claims that it strips the court system of authority (Dolan 2017). 
decide the fate of the death penalty over a more than hundred-year period. It investigates whether those processes are rightly understood as genuine expressions of popular will or are instead occasions on which the public is mobilized and manipulated as part of a broader political struggle. By studying every instance in which the death penalty has been put on the ballot since the early twentieth century, we seek to understand what happens when the death penalty goes public.

We will show that the defeats suffered by abolitionists in 2016 are nothing new. Whatever the era, the form of the ballot question, or the underlying motivations for putting the death penalty to a vote, over the past hundred years abolitionists have consistently taken an electoral beating. They lost twenty-five of the twenty-eight times that voters were offered the chance to express their views on whether to have capital punishment. These results highlight the problem abolitionists face in a political system marked by what scholars have called "criminal justice populism” (Hough 2002).

\section{REFERENDUM AND INITIATIVE: ORIGINS AND CRITICISMS}

The push to establish popular initiatives and referenda of the kind used in 2016 in California, Oklahoma, and Nebraska emerged in the 1890s during an era of political uncertainty. At that time, Americans were struggling "with the harsh economic transformations of an emerging industrial society," and "workers, farmers, consumers, and taxpayers" felt increasingly neglected by politicians and legislators (Piott 2003, 1). They were suspicious of powerful interests, which seemed to "preclude any discussion of vital social, economic, and political issues" (Piott 2003, 1 ). In addition, they were dissatisfied with a "system of governance that rewarded organized power at the expense of the needs of the people" (Piott 2003, 2).

Reformers sought to use democratic processes to circumvent, or check, political institutions, which they felt were dominated by moneyed interests. Progressives saw direct legislation as a way to supplement institutional politics, creating a parallel, democratic system less corrupted by the presence of professional politicians and their interests. The stated aim of those championing initiative and referenda was to return sovereignty to the US people. ${ }^{2}$ They framed their reforms "as efforts to curtail corruption, weaken party bosses, and restore power to ordinary people" (Piott 2003, 2).

It is worth noting that the states that figured prominently in the 2016 elections-Nebraska, Oklahoma, and California-all have long histories of employing initiatives and referenda. Many of the early populists and progressives hailed from the Great Plains, including Nebraska and Oklahoma, laying the framework for a strong tradition of direct democracy that continues to influence politics in the region today (Zisk 1987, 13). California was another early frontier for populists seeking to curtail the power of railroad trusts and to slow Chinese immigration. The state passed a series of reforms, which culminated in the establishment of the direct primary, initiative, referendum, and recall in 1909 under Governor Hiram Johnson (Zisk 1987, 54).

2. For the populist reformers of the 1890 s and, to a lesser extent, the progressives who followed them, these political aims were paired with economic ones (Zisk 1987, 13). 
It would be inaccurate, however, to frame early uses of the initiative and referendum process as untainted expressions of democratic will. Scholars have shown that proponents of direct legislation often were more interested in symbolic reforms than in changes that would actually upset the social and political hierarchies of the day. Moreover, they wanted to limit the political power of immigrants and urban populations (Braunstein 2004, 15).

Since the late 1960s, propelled by increasing distrust of government and a desire to hold elites accountable, the use of initiatives and referenda has greatly increased (Braunstein 2004, 8). At the same time, new questions have arisen about their utility as vehicles for expression of the popular will (Magleby 1994, 246). California, the most prolific user of the referendum process, is a good example. ${ }^{3}$

Putting a measure on the California ballot typically begins with a selfappointed committee deciding on its precise wording. Following this, the state attorney general's office prepares a summary of each proposition. Critics point out that the wording of both the ballot measure itself and the summary "may be so broad and complex as to defeat the attempts of the best-motivated voter to understand it" (DeBow and Syer 2003, 119). The problem of lengthy ballots with legalistic and confusing wording is only compounded farther down the ballot as "voter fatigue" sets in (Debow and Syer 2003, 119).

Critics of initiatives and referenda in the contemporary period also worry about the distorting influence of money and special interest groups. Today, these processes are often a "money game, where average citizens are subjected to advertising blitzes of distortion and half-truths and are left to figure out for themselves which interest groups pose the greatest threats to their self-interest" (Broder 2000, 17).

Financial advantages are especially potent in the challenging first step of collecting petition signatures (Magleby 1984, 61). Those who can afford to do so employ firms such as Kimball Petition Management or the American Petition Consultants of Sacramento, which alone were responsible for the placement of 48 out of 65 initiatives on the California ballot from 1982 to 1992 (Price 1992, 545-48). ${ }^{4}$ Paid signature gathering is not, however, the only means by which powerful special interest groups flex their muscle, as money is also required for elaborate media campaigns.

Instead of simply funding others' referenda campaigns, industries and special interest groups often draft their own ballot measures (Ainsworth 1990). Elisabeth Gerber argues that powerful economic groups are most effective in the referendum process when they use their wealth to maintain the status quo (Gerber 1999, 140). ${ }^{5}$ Overall, Zisk $(1987,108)$ found that 80 percent of the time, the side that spends the most wins.

Many states have attempted to simplify the task of voters and to hinder political chicanery in the process of direct legislation. One result of these efforts is the

3. When referenda are put on the California ballot in special elections, only about 25 percent of eligible voters turn out to vote (Magleby 1994, 247).

4. Following the 1988 case of Meyer v. Grant, in which the prohibition of paid signature gatherers was deemed a violation of the First Amendment, signature gathering tactics have become increasingly elaborate.

5. In California, the power of moneyed interests has significantly increased in recent decades due to the Commission on Campaign Financing's ruling that there could be no spending restrictions on ballot issues in that state (Ellis 2002). The Supreme Court's ruling in First National Bank of Boston v. Bellotti (1978) had a similar effect. It released corporations from restrictions on ballot issue contributions (Hart and Shore 1979). 
so-called single subject rule, which prohibits ballot initiatives from containing multiple subjects. Cooter and Gilbert (2010) write, however, that because judges and legislators have not aptly defined what constitutes a subject, the single subject rule has not offered consistent and reliable regulation of direct legislation. ${ }^{6}$

In addition to concerns about ballot confusion and special interest influence, other scholars worry that the increasing use of ballot initiatives and referenda has a negative impact throughout the political process (DeBow and Syer 2003). Some suggest that direct democracy makes legislators more reluctant to fulfill their responsibilities (Cronin 1999, 140). And, where voters are allowed to express their views on highly charged moral issues, critics note that direct legislation is often used to repress and deny rights to minorities. ${ }^{7}$ Ballot initiatives seem to exemplify the "present tension between fundamental rights and popular opinion" (Cronin 1999, 123). Nowhere is this tension more apparent than when the death penalty is on the ballot.

Ballot measures also have been used as tools of partisan and political advantage. As we will see, this has played a part in the death penalty's ballot history. So-called jack initiatives are designed to increase turnout in one targeted portion of the electorate in order to benefit particular candidates (Kouser and McCubbins 2005, 978). One of the most famous uses of such initiatives was the placement of proposals to ban same-sex marriage on the ballots of eleven states in the 2004 election (Dao 2004). Every one of these measures passed overwhelmingly, and the increased turnout among conservative and Christian voters is widely considered to have been a key factor in George W. Bush's reelection (Donovan, Tolbert, and Smith 2008).

While jack initiatives boost turnout among a specific segment of a party's voters, so-called wedge initiatives are also used for partisan advantage. They serve as "bait" designed to entice the other party to oppose them (Kouser and McCubbins 2005, 976-77). One such example was California Proposition 187 (known as the "Save Our State" initiative), a 1994 measure that sought to deny undocumented immigrants access to state services like healthcare and public education (Kouser and McCubbins 2005, 977). ${ }^{8}$

6. Cooter and Gilbert $(2010,691)$ argue that courts should attempt to determine whether the issues on the ballot are "separable in the minds of the voters." For some death penalty measures, this standard would not completely clear up ballot confusion. Secondary aspects of those initiatives and referenda-such as specifying life without parole as the death penalty's replacement—often follow logically from the main issue of abolition. Nonetheless, their combination complicates voters' reactions to ballot measures.

7. In examining direct legislation from 1959-1993 dealing with issues of racial, ethnic, and sexual orientation minority rights, Gamble (1997) found that an overwhelming majority were written to restrict or repeal civil rights legislation and that efforts to expand rights generally failed. These anti-minority referenda can be understood, Schrag (1998) argues, as expressions of a strain of neo-populism favored by white, affluent, and middle-aged and elderly taxpayers.

8. The initiative was backed by Republican Governor Pete Wilson (who was up for reelection). Prop. 187 was enormously popular in the months leading up to the November election. At the start of his campaign, Wilson trailed his Democratic opponent by as much as twenty points, but he ended up with a decisive victory. Many commentators attribute this reversal to Prop. 187, which was opposed by the Democratic Party (McDonnell 1994).

Prior to the 1994 elections, Grover Norquist, the head of the conservative nonprofit Americans for Tax Reform (ATR), correctly predicted that ballot initiatives cutting taxes and government spending, limiting legislative terms, and increasing parental rights would drive social and fiscal conservatives to the polls and at the same time drain the resources of organizations allied with the Democratic Party which would campaign against the initiatives (Smith and Tolbert 2010). 


\section{THE DEATH PENALTY'S BALLOT HISTORY}

Regardless of whether initiative and referendum are adequate expressions of popular will or are, instead, manipulative tools used by powerful interest groups and political partisans, it is clear that they have played an important, but generally neglected, role in the recent history of America's death penalty. Indeed, since the beginning of the twentieth century, fourteen states, at one time or another, have put the death penalty on the ballot, some more than once.

There have been two distinct periods in the death penalty's ballot history. In the first, from 1912 to 1968 , the question of whether to retain, abolish, or reinstate the death penalty was on the ballot ten times. The second, post-1968, occurred during America's tough-on-crime, law-and-order era. It saw another eighteen instances when the public was called on to vote on capital punishment (Ballotpedia n.d.d). ${ }^{9}$ Occasionally, as in Oklahoma in 2016, voters had to decide whether to change their state constitution to decide the fate of the death penalty.

Early in the twentieth century, death penalty abolitionists were the prime movers in putting the issue on the ballot. In contrast, since 1968, putting the death penalty on the ballot has generally been done by those promoting a "law-and-order" agenda. In this period, voters have been asked to respond to legislative, judicial, or executive actions that threatened to end, or had ended, the death penalty, and ballot measures often have been used by pro-death-penalty politicians to advance their partisan agendas in struggles within, and against, those institutions.

Within this broad periodization, we do not offer a chronological narrative. Instead, we examine initiatives and referenda concerning capital punishment in terms of the purposes to which they have been put and ways they have been used. We do this to assess whether their uses have vindicated the hopes of populist and progressive-era proponents of direct legislation that it would enable voters to check and direct governmental institutions.

\section{Retention, Abolition, and Restoration in the Early Days of the Death Penalty}

Between the first death penalty referendum in 1912 and the beginning of the law-and-order era in 1968, ballot measures dealing with the death penalty occurred only in Oregon, Ohio, Arizona, and Colorado. In this section, we focus on two of those states-Oregon and Arizona-where abolitionists achieved rare, albeit

9. Although thirty-four ballot measures have addressed the death penalty in some way since 1912 , we discuss only twenty-eight of them. Two of the measures we exclude dealt with modes of execution (Arizona 1933 and 1992). In these instances, the results of the referenda created neither a victory nor a defeat for supporters of the death penalty. This was also the case for a referendum in California making changes to the aggravating and mitigating circumstances used in death cases (1978), another in California (1990) pertaining to the definition of "peace officer," and a referendum in Wyoming (1994) that established life without parole while leaving the death penalty untouched.

In 1984, two initiatives were on the Oregon ballot. One (Measure 6) was a constitutional amendment placing the death penalty beyond the scope of the state constitution's prohibition on cruel and unusual punishment, and the other (Measure 7) was a statute implementing the death penalty. Both passed. We treat them as one vote. 
temporary, electoral victories. Governors in both states played leading roles in putting the death penalty on the ballot, and advocacy groups helped shift the tide of public opinion toward abolition. Both states followed an eerily similar pattern in which voters first decided to retain capital punishment, then abolished it, and finally were persuaded to restore it by the kind of law-and-order rhetoric that would flourish half a century later.

\section{Oregon}

In early 1912, Oregon's governor, Oswald West, made a bold and straightforward statement: "capital punishment should be abolished ... in this state" (Morning Oregonian 1911b). Joining forces with allies in the state legislature, he soon began working to put the future of the state's death penalty on the ballot. Once he succeeded in doing so, West announced that he would commute all the state's active death sentences until the voters had the opportunity to decide on the matter (Morning Oregonian 1911a).

The decision to commute was roundly criticized by the public and the media. An editorial in The Morning Oregonian captured the flavor of much of the criticism directed at the governor when it wrote: "No person of sound sense ... believes that it is the province of the Governor to sit as a court of last resort in criminal cases" (Morning Oregonian 1911c). The article accused him of flouting the will of the people to impose his own preferences on the state's penal system. West responded by turning the commutations into reprieves and promising that if the voters decided to retain the death penalty, he would let the men on death row hang (Morning Oregonian 1911e).

The Anti-Capital Punishment League, a vocal abolitionist group, led the charge against the death penalty (Morning Oregonian 1912a). Supporters of the death penalty countered that it saved lives by deterring violent criminals and removing the possibility that convicts could commit acts of murder upon release (Morning Oregonian 1911d). The death penalty, supporters claimed, "is not a clamoring for blood or crying for vengeance" but is instead a necessary tool in protecting citizens (Morning Oregonian 1911f, 8). The Morning Oregonian, which supported capital punishment, denounced West's argument that only poor people received death sentences for their crimes as "miserable sycophancy, pitiful sentimentalism!" (Morning Oregonian 1912b, 8). After a campaign filled with much vitriol, the push to abolish the death penalty lost, 61 percent to 39 percent. West kept his promise and let executions resume.

Inspired by the success of the women's suffrage movement in 1912 and convinced that women voters would help them defeat capital punishment, abolitionists tried again two years later. After a failed effort to work through the legislature (Morning Oregonian 1913), they carried their struggle back to the ballot box (Morning Oregonian 1914b). This time, the initiative they backed sought to ban capital punishment by amending the state constitution (Morning Oregonian 1914c).

The Morning Oregonian exercised considerably more editorial restraint than it did in 1912, though it still expressed a clear preference for retention (Morning Oregonian 1914d). As election day approached, death penalty supporters stoked public 
fear by suggesting that passage of the initiative would lead to the release of previously convicted murderers (Morning Oregonian 1914c). Nonetheless, abolition prevailed, and Oregon became the first state to use the ballot box to end its death penalty, albeit by a margin of just 157 out of the approximately two-hundred thousand votes cast (Morning Oregonian 1914e). ${ }^{10}$

Oregon's abolition lasted just six years. In the period immediately after the 1914 vote, death penalty supporters continued to use stories of particularly gruesome crimes to argue that abolition was a dangerous experiment. The Morning Oregonian declared that a murdered welfare worker "would be alive today if capital punishment had not been abolished in the state of Oregon" (Morning Oregonian $1919 b, 1)$. A state senator called the murder of a deputy sheriff "a sufficient argument for the return of capital punishment" (Morning Oregonian 1919a, 7). The Chief Justice of the Oregon Supreme Court joined in:

The several brutal and cold blooded murders committed in Oregon within the past few weeks should furnish conclusive proof of the need of drastic and uncompromising laws in handling the more desperate class of criminals.... Men who commit murder have no place in society and the quicker they are tried, convicted and sent to the gallows, the better it will be for all concerned. When the man who loiters about the highways and takes human life is safely covered with six feet of earth he will have been robbed of all opportunity to commit further depredations. In sending him to the penitentiary, he fattens off the taxpayer, eventually is paroled or pardoned by some kind-hearted executive and is turned out again to prey on society. (Morning Oregonian 1919a, 7)

While these arguments helped fuel the movement to bring back capital punishment, the state legislature refused to restore the penalty (Morning Oregonian 1920b). It did, however, agree to put the question of reinstating capital punishment on the ballot in the form of a constitutional amendment (Morning Oregonian 1920a). In the 1920 election, 55 percent of voters supported the proposed amendment.

The Oregon story confirms the utility of initiative and referendum as devices in struggles against governmental institutions, first the governor and then the state legislature. It also offers a preview of what would become common after 1968, namely, death penalty supporters effectively using the public's fear to pave the way for the return of the death penalty.

\section{Arizona}

Oregon's pattern of retaining, abolishing, and reinstituting the death penalty was mirrored in events in Arizona. Like Oregon's Governor West, Arizona Governor George Hunt played a key role in starting this cycle. He too announced that he would halt all executions until the public voted on the death penalty (Prescott Weekly Journal-Miner 1913b).

10. An error on the ballot may help explain Oregon's reversal on the death penalty. The 1914 ballot also included a question concerning the prohibition of alcohol, which passed by a wide margin. Both it and the death penalty question were labeled "Amendment 36" (Morning Oregonian 1914a). 
As was the case in Oregon, Hunt's decision elicited fiery rebukes from the state's newspapers. The Bisbee Daily Review reminded the public that Hunt had "sworn to execute [Arizona's] laws, not merely those ones that meet his approval." It warned that Hunt's decision would lay the groundwork for a state where "all laws may set at naught by the same method" (Bisbee Daily Review 1913a, 4). Another editorial criticized the governor's "stubborn disposition," saying Hunt would "rather have no laws at all for the punishment of crime than to have his power restricted" (Bisbee Daily Review 1913b, 4). The Prescott Weekly Journal-Miner claimed that Arizona had become "a nation's laughing stock, if not an object of pity, as a place where a criminal tired of hard work may find a haven of refuge and a good living by contriving to get himself arrested and condemned to State's prison" (Prescott Weekly JournalMiner 1913a, 7). These criticisms turned out to be decisive. In 1914, Hunt's effort to abolish the death penalty at the ballot box lost by a margin of 51 percent to 48 percent. At the same time, Arizona's voters approved a new penal code, a provision of which effectively eliminated the governor's pardoning power.

Soon after the 1914 vote, Hunt defied the law and pardoned several men on death row. However, the state supreme court, by a 2-1 vote, invalidated his action. Undeterred, Hunt called a special legislative session, where his allies pushed through a bill to put the question of abolishing the death penalty to a vote of the general public (Coconino Sun 1914). In November 1916, Arizona's death penalty was ended by a narrow margin, with 18,936 voting "Yes," and 18,784 voting "No" (Arizona State Library n.d.).

As was the case in Oregon, abolition could not hold up in the face of determined death penalty proponents who mounted a fierce campaign and mobilized the public's fear of crime to restore executions. A mere five months after abolition, the Arizona Republican published an editorial titled "Murder and Punishment." It said:

Two murders in this community of the most frightening and revolting character since the people voted to abolish capital punishment last November have raised the question whether or not a mistake was made then.... Whether or not there is any relation between the abolition of the death penalty and these two murders and the increase in murder generally we do not know. It is natural, though, for people to think that life imprisonment is not an adequate punishment. (Arizona Republican 1917, 4)

The Republican's editorial was the first of many to raise this kind of concern.

After a lynch mob hanged a man named Van Ashemore, who had been accused of rape and murder, The Bisbee Daily Review ran an editorial suggesting that Ashemore's killing was "one of the first results" of capital punishment's abolition (Bisbee Daily Review 1917, 1). Lynchings, the editorial suggested, were a natural reaction when the criminal justice system could not satisfy the public's desire for retribution. ${ }^{11}$ According to the paper, "when the proper and merited punishment is

11. David Garland (2005) notes that many white southerners believed that public torture lynchings were legitimate and acceptable punishments. 
not meted out by society's chief guardian-the law-then the law will be taken into the hands of men" (Bisbee Daily Review 1917, 1).

An advocacy group called the Capital Punishment League succeeded in putting the question of reinstating capital punishment back on the ballot (Bisbee Daily Review 1918). Most of the state's newspapers formally endorsed this effort, and, in November 1918, 65 percent of Arizona's voters supported the death penalty. Almost a century later, Arizona retains the death penalty, and only ten other states have carried out more executions since 1976 (Death Penalty Information Center n.d.a).

\section{The Death Penalty on the Ballot in the Law-and-Order Era}

The late 1960s witnessed the beginning of the law-and-order era in US politics (Scheingold 1984). That era birthed broken windows policing, the Willie Horton ads, and massive incarceration rates (Simon 2009). It also saw a substantial spike in support for capital punishment (Gallup n.d.) and changes in the uses of initiatives and referenda about the death penalty.

In this era, the death penalty was on the ballot more frequently, and in more states, than ever before. Of the twenty-eight times that voters have been asked to decide whether or not to have a death penalty, eighteen took place during or after 1968. Fifteen of the post-1968 measures were proposed by those seeking to retain or reinstate the death penalty. Each one of them was approved by the voters. Three ballot questions were proposed by those seeking to abolish capital punishment. None of these three was successful.

In what follows we look first at direct legislation use by capital punishment's supporters and then by those seeking to end it.

\section{Retaining or Reinstating Capital Punishment}

Since 1968, when the death penalty has been put on the ballot, it mostly has been to secure its place in US penology and/or to advance the partisan ends of politicians seeking to show that they were tough on crime. Here, as in the earlier era, initiatives and referenda were instruments of struggle within or against governmental institutions. Ballot measures were proposed by people or groups responding to threats to state killing posed by legislative bodies, courts, or the executive. Those measures were designed to preserve, protect, expand, or reinstate capital punishment, and each one of them achieved its purpose.

Table 1 gives a brief overview of the types of ballot questions proposed during the law-and-order period for the purpose of retaining or reinstating the death penalty, as well as a general timeline for the questions examined in greater detail below.

a. Death penalty supporters: Targeting the legislature. In the law-and-order era, state legislatures generally were eager to enact harsh punishments (Scheingold 1984). However, in several instances, they abolished, threatened to abolish, or refused to reinstate the death penalty. In a few of these cases, death penalty supporters responded by turning to the ballot. The measures they proposed were the product of struggles within the legislature or were proposed by legislators seeking 
TABLE 1.

Ballot Questions Proposed by Death Penalty Supporters in the Law-and-Order Era ${ }^{\mathrm{a}}$

\begin{tabular}{ll}
\hline Type of Ballot Question & \multicolumn{1}{c}{ State and Year } \\
\hline Targeting the Legislature & Massachusetts 1968 \\
Death penalty referenda used to bolster support & Colorado 1974 \\
for capital punishment within divided legisla- & Washington 1975* \\
tures, or to respond to legislative action via the & Wisconsin 2006 \\
ballot & Nebraska 2016* \\
Court Rulings as Targets of Initiative/Referendum & California 1972* \\
Put forward by capital punishment supporters in & Massachusetts 1982 \\
response to court decisions concerning the death & Oregon 1984* \\
penalty & New Jersey 1992 \\
& Ohio 1994 \\
& Florida 1998 \\
& Florida 2002 \\
Targeting a Recalcitrant Executive & California 2016 (Proposition 66)* \\
Death penalty supporters seek to override the & Oklahoma 2016 \\
objections of the governor & Oregon 1978* \\
\hline
\end{tabular}

${ }^{\text {a }}$ The primary purposes and uses of various referenda proposed by death penalty supporters provide the basis for the categorization of different types of ballot questions. Bolded states are examined in more detail within the text.

*Denotes initiative measure.

either to protect or to reinstate the death penalty. In other cases, citizens initiated efforts to reverse legislative action on capital punishment. Three examples of these legislatively focused ballot measures are found in Massachusetts in 1968, in Wisconsin in 1996, and in Nebraska in 2016.

Massachusetts, 1968

In the 1960s, debates over the death penalty were so common in Massachusetts that one commentator remarked on what he called "the annual State House debate over the death penalty," which, he said, would draw "the usual packed house" (Ray 1967, 1). A new abolition bill would inspire spirited debate every year, only to be defeated (Boston Globe 1967a).

In late 1967, two men, each of whom had killed a police officer, were nearing their execution dates, and John Volpe faced the prospect of becoming the first Massachusetts governor in twenty years to send someone to the electric chair. In 1947, Governor Robert F. Bradford had overseen an execution and then promptly lost his bid for reelection (Boston Globe 1967a). Perhaps haunted by Bradford's fate (Michelson 1967), or perhaps responding to his own moral qualms, Volpe sought to avoid this unpleasant responsibility. He asked the state legislature to authorize a study of the deterrent effect of the death penalty and to impose a moratorium on executions until that study was completed. 
Death penalty supporters feared that an official rejection of the deterrence justification would bolster abolitionist efforts. They responded by proposing that a death penalty referendum be put on the ballot in 1968 (Leland 1967). The legislature agreed to do so and wrote the ballot language so that the referendum asked whether the state should retain the death penalty, not whether it should abolish it. One editorial accused the measure's proponents of reversing the wording to "trigger the unthinking 'Yes' vote” (Boston Globe 1967a, 18).

Police throughout Massachusetts forcefully opposed abolition. Their opposition persuaded Richard Cardinal Cushing, the Archbishop of Boston, to remain neutral on the issue. Despite what he acknowledged was a "wide Christian instinct in favor of abolition," Cushing deferred to the "views of law enforcement officers" and did not take a definitive position (Boston Globe 1967b, 15).

In November 1968, 61 percent of Massachusetts voters supported the death penalty, and the referendum had its intended effect on the legislature. When abolitionist lawmakers next proposed an abolition bill, it was soundly defeated (O’Neill 1969).

Wisconsin, 2006

Five years after its admission to the Union in 1848 as America's thirtieth state, Wisconsin's legislature abolished its death penalty. It became the first state to end that penalty for all crimes (Death Penalty Information Center n.d.c). Yet, from time to time, efforts have been made to restore capital punishment. One occurred immediately after the Civil War. Another attempt was made in 1937 to authorize the death penalty for kidnapping after the abduction of Charles Lindberg's son drew nationwide attention (Wisconsin Historical Society n.d.).

Beginning in the early 1990s, Wisconsin state senator Alan Lasee made additional attempts to bring the death penalty back to the state. In 1995, following the Oklahoma City bombing that targeted a federal building containing a day-care center, he proposed a bill to allow juries to recommend death for murderers whose victims were under the age of sixteen (Walters 1995). Public opinion was squarely behind the bill, and the governor promised to sign it if it were passed. The state senate, however, would not take it up (Jones 1995).

Several years later, Lasee tried again. When he could not move a death penalty bill through the legislature, he proposed an advisory referendum. More than a year later, the state senate voted to put the measure on the ballot and the state assembly quickly followed suit. In November 2006, 55 percent of the electorate agreed that the death penalty should be "enacted in the state of Wisconsin for cases involving a person who is convicted of first-degree intentional homicide, if the conviction is supported by DNA evidence" (Ballotpedia n.d.f). In the face of legislative reluctance to embrace capital punishment, the Wisconsin referendum illustrates how death penalty supporters used direct legislation to attempt to overcome institutional resistance to that punishment.

Nebraska, 2016

In January 2015, Nebraska's unicameral legislature voted 32-15 to eliminate the death penalty and replace it with life imprisonment without parole (Duggan 2015a). The abolition effort was led by state senator Ernie Chambers, the state's first African American senator and a long-time crusader against capital punishment 
(Berman 2015). Although Nebraska was not a very active death penalty state (Death Penalty Information Center n.d.b), the legislature's action made national headlines (Berman 2015). As noted in an article in The Atlantic:

The final vote occurred amid a fierce lobbying campaign on both sides, but the outcome was years in the making: In the end, a growing coalition of liberals, religious groups, and libertarian-minded conservatives overcame more traditional tough-on-crime Republicans who saw the death penalty as the appropriate, ultimate punishment for murder. Underlying that ideological debate, however, was a far more pragmatic consideration. Nebraska has been unable to kill any of the murderers sentenced to death by its legal system since 1997. (Berman 2015)

This was not, however, the first time in the law-and-order era that Nebraska's legislature had tried to abolish capital punishment. In 1979, it passed an abolition bill, which was vetoed by the governor. In 1999, it imposed a moratorium on executions while a study was conducted to determine whether the state's death penalty was being fairly applied, and in 2007, the legislature came within one vote of repealing the death penalty (Death Penalty Information Center n.d.b).

As had happened in 1979, the governor vetoed the 2015 bill, but this time the legislature quickly overrode his veto (Duggan 2015b). This seemed to end capital punishment in one of America's reddest states. However, death penalty supporters began the process of the so-called initiative veto, which stopped the bill in its tracks until Nebraska's citizens could vote on whether to abolish capital punishment. Leading the charge on the initiative to block legislative abolition were Nebraskans for the Death Penalty, the Omaha Police Union, Governor Pete Ricketts, and his father, former TD Ameritrade Chairman and Chicago Cubs owner Joe Ricketts (Stoddard 2015). These forces prevailed, and the initiative veto won with 60 percent of the vote.

b. Death penalty supporters: Court rulings as targets of initiative/referendum. Between 1968 and 2016, death penalty supporters in several states turned to direct legislation to reverse what they saw as intrusive court rulings. Judicial opposition to capital punishment emerged just before the dawn of the law-and-order era when the US Supreme Court began to put some teeth into its Eighth Amendment jurisprudence. Thus, in 1958, the Court held that punishments must be compatible with "evolving standards of decency" (Trop v. Dulles 1958, 101), and in 1963, three justices, led by Arthur Goldberg, signaled that they believed state killing might offend those standards (Rudolph v. Alabama 1963). Finally, in 1972, the Court invalidated the death penalty as then administered (Furman v. Georgia 1972).

The death penalty returned four years later (Gregg v. Georgia 1976), but with its return came heightened judicial scrutiny. The US Supreme Court mandated what has been called "super-due process" in death penalty proceedings, and state courts soon followed suit (Bienen 1996, 131). Some of them went even further and ruled that the death penalty violated their state constitutions (Commonwealth $v$. O'Neal [Part II] 1975). Others invalidated specific sentencing protocols, and still others prevented executions after appellate proportionality review (In re Proportionality Review Project 1999). 
In these decisions, courts refused to defer to legislatures and asserted what they claimed to be their role in protecting democratic values. They took aim at what they viewed as government practices hindering the pursuit of dignity and equality and impinging on constitutional rights (Barry 2017). In so doing, they extended the legacy of the Warren Court (Sunstein 2006, 1723). Reacting to the judiciary's death penalty decisions, some politicians tried to arouse public sentiment in a campaign to restore law and order (Simon 2009). Each one of their efforts was successful in turning death penalty referenda into effective mechanisms of popular constitutionalism (Kramer 2006). Below we discuss three examples of those efforts.

Massachusetts, 1982

At the time of the Supreme Court's Furman decision, Massachusetts law authorized the death penalty as a punishment for murder but left the decision to impose a death sentence to the sentencer's discretion in most cases. It made an exception in cases of rape-murder, in which capital punishment was mandatory. Three years after Furman, the Massachusetts Supreme Judicial Court struck down the state's death penalty statute in its entirety (Commonwealth v. O'Neal [Part I] 1975; Commonwealth v. O'Neal [Part II] 1975). Writing for the majority, Chief Justice G. Joseph Tauro found that the state could not meet "its burden of establishing that the death penalty is a necessary and least restrictive means for accomplishment of whatever valid interests it may have" (O'Neal [Part II], 263).

The O'Neal decision provoked a substantial backlash in Massachusetts. Many people and politicians said that it exemplified the dangers of judicial activism and claimed that judges were legislating from the bench (Ozella 1981). Yet it was not until three years after the US Supreme Court's Gregg v Georgia decision (1976) gave the green light to certain sentencing schemes that the Massachusetts legislature passed a new death penalty law. That law authorized death sentences in cases of murder involving "aggravated circumstances." It also provided for separate trials to determine guilt and to decide on the appropriate sentence (Harvey 1980).

However, the new law was short lived. The Supreme Judicial Court, in District Attorney for the Suffolk District v. Watson (1980), threw it out, saying that capital punishment was offensive to contemporary standards of decency. In response to the Watson decision, Governor Edward King urged the legislature to put a constitutional amendment reinstating the death penalty on the ballot (Boston Globe 1981c). The legislature soon gave its assent.

Allied with King in opposition to the court's decision invalidating the death penalty were the Massachusetts Police Chiefs' Union and many tough-on-crime politicians (Kenney 1982). According to the Boston Globe, the death penalty presented "the most polarizing issue" of the 1982 election (Robinson 1982, 1). Throughout that campaign, candidates and citizens in Massachusetts vented their frustration with the courts for defying the will of the people. A letter to the editor of the Boston Globe captured this sentiment: "[A previous referendum held in 1968] reflected the wishes of the voters to bring back capital punishment. And yet these 'justices,' in their arrogance and hypocrisy, laughed at the masses. When will they stop playing God and realize that too many killers are paroled and sent out into society to kill again?" (Ozella 1981, A6). 
Governor King also used the 1982 referendum as a key part of his primary campaign against Michael Dukakis, whom he had defeated four years earlier. At the time he proposed the death penalty referendum, King was burdened with a public image of incompetence and his failure to follow through on a campaign promise of property tax cuts (Boston Globe 1981b). In addition, his administration was dogged by corruption scandals (Globe State House Bureau 1982). The one issue with which he had success was crime. Indeed, King credited "taxes, abortion and capital punishment” for his 1978 primary victory over Dukakis (Nyhan 1981, 67).

The ballot measure King proposed was a classic wedge referendum. Ordinarily, wedge tactics are most useful against members of another party but, with two-thirds of Massachusetts voters supporting capital punishment, King thought the tactic could aid him in his primary battle (Boston Globe 1981a). As a result, he made the death penalty a centerpiece of his campaign and, at every opportunity, tried to force Dukakis to discuss his opposition to it. In addition, he continually raised the possibility that Dukakis would broadly commute death sentences if he were elected governor (Lockman 1982). These tactics were not enough to save King from being defeated in the September primary.

Two months later, however, King's position prevailed when the voters delivered a stern rebuke to the courts. Some 60 percent endorsed the ballot measure stating that "no constitutional provision shall be construed as prohibiting the death penalty."

Florida, 1998

A decade and a half later, a similar saga of a ballot measure designed to curb the judiciary unfolded in Florida. In the law-and-order era, that state has been among the leading death penalty states. While its last pre-Furman execution occurred in 1964, Florida was the first state to reenact a death penalty after Furman. In addition, the state's death penalty history has long been associated with its use of the electric chair, which was first used in the state in 1924 (Florida Department of Corrections n.d.).

Following a series of brutally botched executions in the 1990s, a death row inmate, Leo Alexander Jones, asked the state courts to rule on the constitutionality of the electric chair. After a trial judge refused to find its use unconstitutional, Jones appealed to the state's supreme court. That court ruled, 4-3, that Jones's claims were "totally without merit" and held that only if an execution entailed "torture or a lingering death" would it be impermissibly cruel (Jones v. State 1997, 79).

However, Justice Stephen Grimes, a member of the majority in the 1998 ruling, retired shortly after the decision. In his place, Democratic Governor Lawton Chiles nominated Barbara Pariente, whose stance on the electric chair was unknown. Rather than take a chance on the new justice, the Florida legislature decided to take the issue out of the court's hands altogether.

State representative Victor Crist proposed the "Preservation of the Death Penalty Amendment," which he said would "forbid the state Supreme Court from overturning capital punishment unless the US Supreme Court did the same thing" (Hauserman 1998, 5B). This amendment removed from the Florida Supreme Court the authority to interpret the state's "cruel and unusual punishments" clause in any 
domain, not just capital punishment. Following a campaign laden with the lawand-order, tough-on-crime rhetoric, in November 1998, 72 percent of the voters supported the amendment.

Florida, 2002

Two years later, a four-justice majority of the state supreme court held that the language of the 1998 initiative was misleading and that it violated Article XI of the Florida Constitution, which outlines the procedure for legislatively referred constitutional amendments (Armstrong v. Harris 2000). Critics saw this ruling as another example of judicial overreach. They said it ignored the popular will for the sake of enhancing the court's own power.

Legislators moved quickly to put a new constitutional amendment on the ballot, setting up another battle with the courts for the voters to resolve (Kumar 2002). As one article in the St. Petersburg Times noted: "Perhaps the saddest part of this predicament is that this constitutional amendment wasn't needed. It was on the ballot because the Republican-controlled Legislature wanted to take revenge on the Florida Supreme Court" (St. Petersburg Times 2002, 2D).

The language of the amendment, which was put to the voters in the 2000 election, was identical to the one the court had just invalidated. The legislature changed only the summary that was offered with it. That summary was, however, much longer than the actual amendment text. The referendum's opponents called the summary a "confusing monstrosity" (Wasson 2002, 1). Echoing concerns in the scholarly literature about ballot confusion, the St. Petersburg Times also warned that "a voter without a law degree and a special interest in Tallahassee gamesmanship is not going to understand the wording of, or the impetus behind, Amendment 1" (St. Petersburg Times 2002, 2D).

Nonetheless, the public responded enthusiastically to the law-and-order campaign of death penalty proponents and their criticism of the state supreme court's judicial activism. The amendment passed by a margin almost identical to the margin of two years earlier.

c. Death penalty supporters: Targeting a recalcitrant executive. Along with legislatures and courts, death penalty referenda also targeted the actions of state governors. One example of this use of death penalty ballot measures occurred in Oregon. A few years before Nixon's southern strategy added fuel to the law-and-order era, Oregon voters, in 1964, abolished the death penalty for the second time in the state's history. By 1977, Oregon had been without a death penalty for thirteen years, more than twice the duration of the earlier period of abolition (from 1914 to 1920). However, that year saw the Golden Dragon Massacre, a massive hostage situation in Washington, DC, the Son of Sam killings, and James Earl Ray's escape from prison. Moreover, serial killers Ted Bundy, Richard Chase (the "Vampire of Sacramento"), the Hillside Strangler, and John Wayne Gacy all made headlines (Bergeron 2015).

Oregon legislators reacted to these high-profile crimes by calling for the restoration of the death penalty. However, Governor Bob Straub, a vociferous opponent of state killing, vowed to veto any such legislation. Enough legislators opposed the death penalty that a veto override was out of the question (Cogswell 1977). Putting 
TABLE 2.

Ballot Questions Proposed by Death Penalty Opponents in the Law-and-Order Era

\begin{tabular}{ll} 
Type of Ballot Question & \multicolumn{1}{c}{ State and Year } \\
\hline $\begin{array}{l}\text { Targeting the Legislature } \\
\text { Proposed following legislative failure to abolish } \\
\text { the death penalty }\end{array}$ & Callinois 1970 \\
$\begin{array}{l}\text { Targeting the Courts } \\
\text { Put forward following a reversal of an abolition- } \\
\text { ist court ruling }\end{array}$ & California 2016 (Proposition) 62* \\
\hline
\end{tabular}

*Denotes initiative measure.

the restoration of the death penalty on the ballot offered a way to circumvent the governor's intransigence.

During the 1978 campaign, powerful voices spoke out on both sides of the issue. The Oregonian, reversing its early twentieth-century pro-death-penalty stance, published multiple pieces arguing against reinstatement, urging voters not to "reverse the humane spirit of earlier Oregon elections" (Oregonian 1978). The Oregon Council Against the Death Penalty boasted several high-profile figures as members, including Governor Straub, Bob Duncan, a congressman from Oregon's Third District, and a handful of other state and local officials, including sheriffs and prison wardens (Cogswell 1978).

Supporters of capital punishment argued that "Oregon should have a last resort remedy to deal with those persons who defy all senses in their murder episodes" (Hartman 1978, B6). Scott McAlister, the state's assistant attorney general, summed up the arguments favoring restoration. "Some crimes are so bad," he said, that "the person ought not to see society ever again" (Ota 1978, B5).

In November 1978, 64 percent of voters supported the restoration measure and, in so doing, brought the death penalty back to their state over the objections of its abolitionist governor.

\section{Seeking to End Capital Punishment}

Three times in the post-1968 period, abolitionists used direct legislation in their efforts to end the death penalty (see Table 2). Like death penalty supporters, abolitionists who spearheaded initiatives and referenda did so in response to adverse governmental action. In each of those instances, their hopes were dashed at the polls. When legislative bodies balked at abolition or threatened to bring back the death penalty, the populace supported them. When courts would not strike down the death penalty, the people would not either.

\section{a. Death penalty opponents: Targeting the legislature}

Illinois, 1970

In 1968, the US Supreme Court invalidated Illinois's death penalty statute, which allowed prosecutors unlimited voir dire challenges to exclude jurors who had moral 
qualms about capital punishment. The Court ruled that while jurors who are flatly unwilling to impose a death sentence may be excluded, jurors who merely express uncertainty about state killing cannot be excluded for that reason alone. The case, Witherspoon v. Illinois (1968), nullified the sentences of Illinois's death row population, including Richard Speck, a serial killer convicted of the brutal rape and murder of eight Chicago nurses.

The Witherspoon decision and the prospect of emptying death row set off a legislative scramble to retool the state's sentencing system (Kilian 1969a,b), which quickly succeeded. At the same time, Illinois voted to hold a convention to consider whether to draft a new state constitution that could be put up for referendum approval in 1970. Abolitionists hoped that the convention delegates might be more responsive to their cause than the state legislature had been in its post-Witherspoon deliberations.

Early in the convention, an attorney whom the Chicago Tribune described as a "maverick democrat" proposed that the new a constitution should include a provision that "no penalty shall prescribe death" (Elmer 1970b, 22). The convention president enthusiastically supported the abolition measure. He said, "I wish that the convention would stand up and say that the right to human life is a matter to be dealt with in this constitution" (Herman 1970, 10).

Death penalty supporters argued that the decision about whether to have such a punishment should not be taken out of the hands of the legislature. They said that while "no one should take the life of another unless there is no other way to protect individual rights ... there are few executions now, but there might come a time when crime is so rampant that there is no other recourse" (Herman 1970, 10). This view prevailed, and the convention defeated the abolition proposal 54-50 (Herman 1970). Yet abolitionists were able to get the delegates to agree to put the question of the death penalty's future to the voters in a special referendum.

Death penalty supporters decried the possibility that the voters would unleash "brutes who stop at nothing and understand only the law of the jungle ... they leave behind them the torn, dismembered bodies of their victims ... it's become insane" (Elmer 1970a, 1). Thomas Kellegham, whom the Chicago Tribune called "the convention's most outspoken proponent of capital punishment," struck a calmer and more confident note. The death penalty, he noted, existed because the public wanted it. Another vote, he was sure, would confirm that trend (Elmer 1970a, 1).

As was the case in other states, putting the death penalty on the Illinois ballot mobilized interest groups and civic organizations, including the Independent Voters of Illinois, a coalition of liberal independents, the Chicago and Illinois State Bar Associations, the Chicago Urban League, the Union League Club of Chicago, the Illinois Division of University Women, the Illinois Commission for Abolition of Capital Punishment, and Jesse Jackson's Operation Breadbasket (Chicago Tribune 1970a, 1970b; Strong 1970a, 1970b; Wolfe 1970; Kleiman 1971). However, the state's Democratic Party did not take a position on the death penalty question, silencing what could have been a powerful voice for abolition (Chicago Tribune 1970c). In addition, The Chicago Tribune formally endorsed a "No" vote on the death penalty ballot question, saying that "the evidence is not sufficient to convict 
the death penalty of either failure or immorality ... if the mere existence of the death penalty on the statute books prevents one murder, it will have justified itself" (Chicago Tribune 1970e, 12).

In the 1970 election, Illinois's voters sided with the state legislature and the constitutional convention and embraced the death penalty, with more than 54 percent saying "No" to the ballot proposition. Reflecting the law-and-order tenor of the campaign, a Chicago Tribune postmortem interpreted the ballot measure's rejection as showing that "a majority of the people are alarmed by the mounting crime rates and are ready to sanction stern measures against criminals" (Chicago Tribune 1970d, 8).

\section{California, 2012}

The year 2012 marked the fourth time that a ballot question dealing with the death penalty had been on the California ballot since 1972. No state has used direct legislation concerning capital punishment more in the post-1968 period. The 2012 initiative campaign was spurred, in large part, by the release of a massive study of the costs of California's capital punishment system. That study showed that between 1978 and 2011, over four billion dollars in state and federal spending had gone toward California's death penalty. With the thirteen prisoners put to death in that time, the cost of each execution was approximately $\$ 300$ million (Alarcón and Mitchell 2011). Responding to this study, Lori Hancock, a Democratic state senator from Oakland and a member of the Senate Budget Committee, introduced SB 490, which proposed to replace the death penalty with life imprisonment without parole. However, it generated little support in the state legislature and never came up for a vote (Fischer 2011).

Nonetheless, media coverage of the bill and the findings of the report on the death penalty's costs spurred California's abolitionist community to use the initiative process to do what the legislature would not do and to do what retentionists had done successfully for decades, namely, circumvent their political leaders. The California Taxpayers for Justice launched a drive to collect the 504,760 signatures needed to put an initiative on ballot (Sanders 2011). At the same time, former San Quentin State Prison Warden Jeanne Woodford started promoting the so-called Savings, Accountability, and Full Enforcement for California Act, or SAFE California, which would replace California's death penalty with life in prison without the possibility of parole (Woodford 2012). Initially, SAFE California recruited law enforcement leaders, prison officials, wrongly convicted persons, and family members of murder victims. As this effort gained momentum, it relabeled its proposal "Proposition 34" and combined forces with Taxpayers for Justice.

Reflecting changes occurring across the country (Sarat et al. 2017), abolitionists used a new strategy, largely eschewing the more familiar moral arguments against state killing and focusing instead on the cost of California's death penalty (Maiman 2012; Skelton 2012). "The campaign isn't about a moral opinion of the death penalty," said Daisy Vieyra, communications assistant for Yes on Proposition 34. "It's about what is actually happening in the state of California... Right now, with our state's budget cuts, it doesn't really seem feasible to fix or have [the death penalty]" (Goldberg, Levinson, and Hellerstein 2012). As Sacramento attorney Don 
Heller put it, "[e]ven when you address the issue of potentially executing an innocent person, it's the cost that resonates. All of a sudden it's being brought home, when counties are going bankrupt and cities are going bankrupt, that there's just not enough money out there" (Stanton 2011, A3).

Money saved from the death penalty, proponents contended, could be redirected to more useful purposes in the criminal justice system. Savings Accountability and Full Enforcement, or SAFE, another pro-Prop. 34 group, said that "condemned inmates would be given life without the possibility of parole and would be required to work in prison" (Stanton 2011, A3). Additionally, the money saved from abolishing capital punishment "would flow into the SAFE California Fund over four years, which could be used by police departments, sheriffs and district attorney offices for the purpose of "increasing the rate at which homicide and rape cases are solved" (Sacramento Bee 2012, A14). The Sacramento Bee reversed "the editorial board's long-standing support for California's death penalty," concluding that "the death penalty is unworkable and unfixable in California" (Sacramento Bee 2012, A14). The slow, costly state killing process became the main talking point of the campaign for Proposition 34: "Death penalty opponents in California are trying a new argument this year: Abolish capital punishment because the perpetually cashstrapped state just can't afford it" (Elias 2012, A23).

Reflecting the concerns of critics of direct legislation, the pro-Prop. 34 campaign cost more than $\$ 7,000,000$, with $\$ 2,000,000$ being donated by just two donors (Ballotpedia n.d.a). Opponents of the initiative were much more modestly funded and spent just under $\$ 400,000$ (Ballotpedia, n.d.a). Opposition was largely organized by the Peace Officers Research Association of California, with support from other law enforcement groups (Los Angeles Times 2012). Reflecting the strategy used in many previous campaigns to preserve the death penalty, groups seeking to defeat the proposition claimed that passage of the proposition "would let serial killers, cop killers, child killers, and those who kill the elderly, escape justice. Proponents don't acknowledge that when California's death penalty was eliminated before, condemned criminals were released only to rape and kill again" (Goldberg, Levinson, and Hellerstein 2012). The anti-Prop. 34 campaign claimed that "instead of justice, killers [would] get lifetime housing/healthcare benefits" if Proposition 34 passed (Mitchell 2013).

Moreover, opponents of the measure argued that the death penalty itself was not the problem. While abolitionists targeted legislative inaction, opponents portrayed themselves as respecting the will of the people. They defended the legislature and tried to shift the public's attention to court procedures that imposed what they saw as undue delays in the death penalty system. They blamed liberal activist groups for going to court to prevent California from using its death penalty and pointed to the suffering imposed on victim families by extended and unnecessary legal proceedings. One op-ed arguing in favor of retention read:

to argue against the death penalty by stating it's too expensive for California is intellectually dishonest and disrespectful to the victims of the state's most heinous criminals... The same people pushing for Proposition 34the American Civil Liberties Union, among others-are the ones primarily responsible for California spending too much on death row prisoners in 
the first place. Legal delays caused by the ACLU and others are a big reason why California has executed only 13 people since 1978 at a cost of $\$ 4$ billion. (Breton 2012, B1)

Voters, retentionists argued, should not reward abolitionists for using the courts to do what the people and their elected representatives would not do, namely, end capital punishment. Michael Ramos, San Bernardino County District Attorney, and leading opponent of Prop. 34, said: "You want to save money, let's start carrying out the will of the voters and putting the prisoners on death row to death" (Ballotpedia n.d.a). In the end, Prop. 34 was defeated and California's death penalty survived, by a vote of 52 percent to 48 percent (Ballotpedia n.d.a).

\section{b. Death penalty opponents: Targeting the courts}

California, 2016

Four years after the defeat of Proposition 34, the death penalty was back on the ballot in California. Proposition 62 offered the voters a chance to replace it with life in prison without parole. Abolitionists were prompted to try again, in part, by the narrowness of Proposition 34's defeat. As one death penalty opponent noted: "This almost even division of voters sends a signal that the public will tolerate judicial scrutiny of the death penalty. Elected officials who have assumed that taking a stand against capital punishment was a high-risk venture now know that the political price tag for moral leadership is much lower in 2012 than it has been in a generation" (Zimring 2012).

But 2016 was different from 2012, in part because opponents of abolition succeeded in getting a countermeasure (Proposition 66) on the ballot (Puri 2016). In addition to the narrow defeat of Proposition 34 in 2012, the campaign over the twin death penalty initiatives on California's 2016 ballot was shaped by various judicial rulings. Abolitionist efforts to use the ballot to end the death penalty were fueled by a federal judge's 2014 decision that the way California carried out its death penalty constituted cruel and unusual punishment (Jones v. Chappell 2014) and the reversal of that decision one year later by the Ninth Circuit Court of Appeals (Jones v. Davis 2015).

As they did four years earlier, death penalty opponents insisted that it was time to end the money pit of state killing. The death penalty's supporters, who included most of the state's district attorneys, again tried to shift the rhetorical terrain. They insisted that the death penalty is the only way to provide justice to victims. "Crime victims will feel once again that the system has failed them," said San Mateo DA Steve Wagstaffe. "And the concept of life without parole-they simply don't believe it" (Shafer 2016).

Like other instances when the death penalty has been put on the ballot, abolitionists were divided over resorting to direct legislation as well as over the merits of the particular ballot question. Thus, in the run up to the 2016 referendum, they debated whether to support Proposition 62. While most supported it, some critics of capital punishment refused to do so. They contended that the replacement of capital punishment with mandatory life in prison without parole amounted to the substitution of one kind of death penalty with another kind (Dow 2012; Ogletree and Sarat 2012; Meisel 2016). 
California's 2016 experience offers an instance in which some criticisms of ballot measures played out while others did not. Both sides were very well financed. Supporters of Proposition 66 spent $\$ 13,000,000$. Opponents also spent a comparable amount (Ballotpedia n.d.b). Silicon Valley executives, including Netflix CEO Reed Hastings and Emerson Collective founder Paul Graham, themselves contributed \$4.2 million to qualify and promote Proposition 62 (Ulloa 2016).

At the same time, California's 2016 death penalty measures offer vivid examples of ballot confusion and fatigue. Supporters of the death penalty effectively muddied the waters for California voters by getting Proposition 66 on the ballot at the same time as Proposition 62 (Sanburn 2016). In addition, Propositions 62 and 66 were just two of seventeen ballot measures in 2016, the most initiatives for any election since March 2000. Newspapers certainly picked up on the potential implications of this, with headlines proclaiming that the ballot was "massive," "intimidating," "crowded," and that it held a "torrent" of questions, a "truckload of propositions" (Artz 2016, A1).

The prolixity of the 2016 ballot was especially pertinent on the issue of the death penalty — articles such as "Conflicting Death Penalty Ballot Measures to Appear in Upcoming Election" attempted to carefully explain what casting "Yes" or "No" votes would mean for each measure (Reeves 2016). However, it became even harder to clarify which ballot carried which meaning as the campaign went onProposition 62 meant to repeal the death penalty. Proposition 66 sought to reform the death penalty. The later was promoted through a campaign calling on voters to vote "No on 62, Yes on 66." A group opposing 66, formally named Taxpayers for Sentencing Reform, launched a campaign with the slogan "Yes on 62, No on 66" (Padilla n.d.). Studies showed that one in ten voters gave up reading ballots before they reached the end; Propositions 62 and 66 were both in the bottom third of the measures on the ballot (Padilla 2016).

Moreover, some voters, as well as pundits, seemed misled as to the actual effects of each measure. One voter explained that she would be supporting Proposition 66 because "it would mean inmates would work while waiting for their sentence, while with 62 they would only have more time in prison" (Reyes 2016). Comparing 66 and 62, a Los Angeles Times article also pointed out this component of 66: "Proposition 66 would require death-row inmates to work to pay compensation to victims' families and bar medical associations from disciplining doctors who participate in executions" (Dolan 2016). Yet one of the arguments in favor of Proposition 62 was that "criminals who would otherwise sit on death row and in courtrooms during the decades-long appeals guaranteed by the Constitution, will instead have to work and pay restitution to their victims' families" (Padilla 2016). Buried under the blizzard of claims and counterclaims that inundated the 2016 ballot process, proponents of Propositions 66 and 62 found it hard to ensure that the voting public had an accurate understanding of either measure.

\section{CONCLUSION}

The history of ballot measures concerning the death penalty confirms several of the hopes of populist and progressive-era proponents of direct legislation, and it 
illustrates the ways the public can resist, or overcome, decisions of their political leaders. Moreover, some of the defects that critics of direct legislation highlight do not play prominent roles in that history. For example, with the exception of California and Nebraska, big money has not regularly been a major factor in determining the outcome of these ballot measures.

Yet the story of what happens when the death penalty is on the ballot is not uniformly positive for advocates of initiative and referendum. For example, in addition to allowing voters to check political leaders and institutions, ballot measures, as we noted above, have been used by political leaders to mobilize and direct public sentiment. Furthermore, the death penalty's ballot history has been marked by instances of the kind of ballot confusion that worries direct legislation's critics.

Whatever the complexities and problems of any particular ballot question dealing with capital punishment, examining what happens when the death penalty goes public demonstrates that since 1968, referendum and initiative measures have played a prominent role in stopping efforts to end capital punishment. When courts ruled against the death penalty or when legislatures voted to abolish it, the initiative or referendum process was used against them. When an executive would not sign a restoration bill, the death penalty was put on the ballot to circumvent him or her.

These results confirm the arguments of scholars that the public seems to be more punitive than elites (Gross 1993; Whitman 2003; Garland 2010). As Garland (2010, 309) notes, America's death penalty has not been abolished because of the resilience of America's system of "popular local democracy," which has stood strong against what he calls "top-down counter-majoritarian reform." Death penalty supporters repeatedly emphasize these public preferences and call on other politicians to respect the "will of the people." In their view, efforts to end the death penalty are undemocratic.

While many scholars advance concepts of democracy that go beyond simple majority rule (Kateb 1994; Dryzek 2000; Gutmann and Thompson 2004; Post 2005) and argue that the death penalty is incompatible with democracy (Bedau 1992; Johnson 2004; Kateb 2011), Samuel Gross notes that "whenever the death penalty has been abolished in a Western country it would have been retained if that matter had been put to a public vote" (Gross 1993, 87; see also Steiker and Steiker 2016). No matter what one's conception of democracy, or what one thinks about its compatibility with capital punishment, the history of the death penalty on the ballot suggests that Gross's (1993) observation is as applicable to the United States as it has been in other jurisdictions. Abolition, if it occurs in America, will likely be the work of legislators, executives, and, most especially, judges (Caplan 2016; Richardson 2016; Steiker and Steiker 2016). It will, in Whitman's $(2003,13)$ terms, be an "elite" project.

\section{REFERENCES}

Ainsworth, Bill. "Initiative Wars: If You Can't Beat 'Em, Swap 'Em.” California Journal, 21 (1990): 147-49. 
Alarcón, Arthur, and Paula M. Mitchell. "Executing the Will of the Voters?: A Roadmap to Mend or End the California Legislature's Multi-Billion-Dollar Death Penalty Debacle." Loyola of Los Angeles Law Review 44 (2011): 41-221. http://digitalcommons.lmu.edu/llr/vol44/ iss $0 / 1 /$.

Arizona Republican. "Murder and Punishment." Arizona Republican, May 6, 1917, 4.

Arizona State Library. n.d. "Initiative and Referendum Publicity Pamphlets." http://azmemory. azlibrary.gov/cdm/compoundobject/collection/statepubs/id/10531/rec/4.

Artz, Matthew. "Massive Ballot Awaits Voters: Awash in Alternatives with 17 Statewide Measures in November." Mercury News, July 5, 2016, A1.

Ballotpedia. "California Proposition 34, The End the Death Penalty Initiative (2012)." n.d.a. https://ballotpedia.org/California_Proposition_34,_the_End_the_Death_Penalty_Initiative_(2012). . "California Proposition 62, Repeal of the Death Penalty (2016)." n.d.b. https://ballotpedia. org/California_Proposition_62,_Repeal_of_the_Death_Penalty_(2016).

. "California Proposition 66, Death Penalty Procedures (2016). n.d.c. https://ballotpedia.org/ California_Proposition_66,_Death_Penalty_Procedures_(2016).

"Death Penalty on the Ballot." n.d.d. https://ballotpedia.org/Death_penalty_on_the_ ballot $\#$ tab $=$ By_year.

. "Oklahoma Death Penalty, State Question 776 (2016)." n.d.e. https://ballotpedia.org/ Oklahoma_Death_Penalty,_State_Question_776_(2016).

"Wisconsin Death Penalty, Question 2 (2006)." n.d.f. https://ballotpedia.org/Wisconsin_ Death_Penalty,_Question_2_(2006).

Barry, Kevin. "The Death Penalty and the Dignity Clauses." Iowa Law Review 102 (2017): 383-444.

BBC "Support for Death Penalty Drops Below 50\% for First Time." BBC News, March 26, 2015. http://www.bbc.com/news/uk-32061822.

Bedau, Hugo Adam. "The Eighth Amendment, Dignity, and the Death Penalty." In The Constitution of Rights, edited by Michael Meyer and William Parent, 145-71. Ithaca, NY: Cornell University Press, 1992.

Bergeron, Ryan. “'The Seventies:' The Decade's Worst Killers.” CNN, August 17, 2015. http:// www.cnn.com/2015/07/08/entertainment/the-seventies-the-decades-worst-killers/index.html.

Berman, Russell. "How Nebraska Abolished the Death Penalty." Atlantic, May 27, 2015. https:// www.theatlantic.com/politics/archive/2015/05/how-nebraska-banned-the-death-penalty/394271/.

Bienen, Leigh. "The Proportionality Review of Capital Cases by State High Courts After Gregg: Only the Appearance of Justice." Journal of Criminal Law and Criminology 87 (1996): 130-314.

Bisbee Daily Review "The Governor and Capital Punishment." Bisbee Daily Review, April 11, 1913a, 4.

—. "The Penal Code and the Governor." Bisbee Daily Review, April 29, 1913b, 4.

—. "Masked Mob at Phoenix Lynches Slayer of Gibson." Bisbee Daily Review, May 8, 1917, 1.

. "Ask Assistance in Plan to Reestablish the Death Penalty." Bisbee Daily Review, May 31, 1918, 2.

Boston Globe "Massachusetts Demeaned." Boston Globe, March 1, 1967a, 18.

_ . "Prelate Refuses Stand Now on Death Penalty." Boston Globe, April 10, 1967b, 15.

"Gallup Poll: Support Rises for the Death Penalty." Boston Globe, March 1, 1981a, 13.

"Massachusetts Poll: Wide Dukakis Lead in 3-Way Contest." Boston Globe, October 18, 1981b, 25.

—. "Text of Governor King's Message." Boston Globe, January 13, 1981c, 22.

Braunstein, Richard. Initiative and Referendum Voting: Governing Through Direct Democracy in the United States. New York: LFB, 2004.

Breton, Marcos. "Dishonesty in Prop. 34 Campaign." Sacramento Bee, September 5, 2012, B1.

Broder, David. Democracy Derailed: Initiative Campaigns and the Power of Money. New York: Harcourt, 2000.

Caplan, Lincoln. "The Growing Gap Between the US and the International Anti-Death Penalty Consensus." New Yorker, December 31, 2016. http://www.newyorker.com/news/news-desk/ the-growing-gap-between-the-u-s-and-the-international-anti-death-penalty-consensus.

Chicago Tribune "2 More Groups Support Charter." Chicago Tribune, November 20, 1970a, 6. 
—. "Daley Pushes Drive for New Constitution." Chicago Tribune, December 5, 1970b, 5.

"Democrats Meet on Con-Con." Chicago Tribune, November 28, 1970c, 4.

"Results of Election." Chicago Tribune, December 17, 1970d, 8.

"Two Issues of Principle. Editorial." Chicago Tribune, December 12, 1970e, 12.

Clark, Bianca. "Trump's Support for the Death Penalty Puts Him on the Wrong Side of History."

The Hill, March 29, 2017. http://thehill.com/blogs/pundits-blog/crime/326388-trumps-support-

for-the-death-penalty-puts-him-on-wrong-side-of-history.

Coconino Sun "Governor Hunt Calls Second Extra Session." Coconino Sun, June 4, 1914, 2.

Cogswell, Phil. "Capital Punishment to Get Salem Hearing." Oregonian, February 5, 1977, A18.

—. "Tax Measures Not Alone on Ballot." Oregonian, September 24, 1978, B4.

Cooter, Robert D., and Michael Gilbert. "A Theory of Direct Democracy and the Single Subject Rule." Columbia Law Review 110 (2010): 687-730.

Cronin, Thomas. Direct Democracy: The Politics of Initiative, Referendum, and Recall. Bloomington, IN: iUniverse, 1999.

Dao, James. "Same Sex Marriage Issue Key to Some G.O.P. Races." New York Times, November 4, 2004. http://www.nytimes.com/2004/11/04/politics/campaign/samesex-marriage-issue-keyto-some-gop-races.html?_r=0.

Death Penalty Information Center "Executions by State and Year." n.d.a. https://deathpenaltyinfo.org/node/5741\#NE.

. "Nebraska." n.d.b. https://deathpenaltyinfo.org/nebraska-1.

"Wisconsin." n.d.c. https://deathpenaltyinfo.org/wisconsin-0.

DeBow, Ken, and John C. Syer. Power and Politics in California. New York: Longman, 2003.

Dolan, Maura. "Trying to Speed Up Executions Could Deal 'Mortal Blow' to California Supreme Court." Los Angeles Times, April 2, 2016.

. "Executions Could Resume After California Supreme Court Leaves Most of Proposition 66 Intact." Los Angeles Times, August 24, 2017. http://www.latimes.com/local/lanow/la-me-lndeath-penalty-decision-prop-66-20170824-story.html.

Donohue, John J., and Max Schoening. "Jeff Sessions, the Grim Reaper of Alabama." New York Times, January 8, 2017. https://www.nytimes.com/2017/01/08/opinion/jeff-sessions-the-grimreaper-of-alabama.html.

Donovan, Todd, Caroline Tolbert, and Daniel A. Smith. "Priming Presidential Votes by Direct Democracy." Journal of Politics 70 (2008): 1217-31.

Dow, David R. "Life Without Parole: A Different Death Penalty." Nation, October 26, 2012. https://www.thenation.com/article/life-without-parole-different-death-penalty/.

Dryzek, John. Deliberative Democracy and Beyond: Liberals, Critics, Contestations. New York: Oxford University Press, 2000.

Duggan, Joe. "Bill to End Death Penalty Passes-Lawmakers Turn Their Attention to Override on Expected Veto by Governor-How They Voted." Omaha World-Herald, May 20, 2015a, 1A.

. "Ricketts Overriden, Death Penalty Out. Omaha World-Herald, May 28, 2015b, 1A.

Elias, Paul. "Cost at Issue in Death Penalty Debate." Los Angeles Times, November 2, 2012, A23.

Ellis, Richard. Democratic Delusions: The Initiative Process in America. Lawrence, KS: First University Press of Kansas, 2002.

Elmer, John. "Death Penalty Put to Voters." Chicago Tribune, August 6, 1970a, 1.

—. "Submit Crime Law Proposal to Con-Con." Chicago Tribune, February 5, 1970b, 22.

Fischer, Mary. "The Appeal of Death Row." Atlantic, November 2011. https://www.theatlantic. com/magazine/archive/2011/11/the-appeal-of-death-row/308662/.

Florida Department of Corrections "Death Row." n.d. http://www.dc.state.fl.us/oth/deathrow/.

Gallup "Death Penalty." n.d. http://www.gallup.com/poll/1606/death-penalty.aspx.

Gamble, Barbara. "Putting Civil Rights to a Popular Vote." American Journal of Political Science 41, no. 1 (1997): 245-69.

Garland, David. "Penal Excess and Surplus Meaning: Public Torture Lynchings in TwentiethCentury America." Law and Society Review 39, no. 4 (2005): 793-833.

—. Peculiar Institution: America's Death Penalty in an Age of Abolition. Cambridge, MA: Belknap Press of Harvard University Press, 2010. 
Gerber, Elizabeth R. The Populist Paradox. Princeton, NJ: Princeton University Press, 1999.

Globe State House Bureau "King's Record: Hits and Misses." Boston Globe, January 24, 1982, 1.

Goldberg, Jamie, Alana Levinson, and Erica Hellerstein. "Prop. 34: Will California Abolish the Death Penalty?" Mission Local, November 3, 2012. https://missionlocal.org/2012/11/prop-34will-california-abolish-the-death-penalty/.

Gross, Samuel. "The Romance of Revenge: Capital Punishment in America." Studies in Law, Politics, and Society 13 (1993): 71-104

Gutmann, Amy, and Dennis Thompson. Why Deliberative Democracy? Princeton, NJ: Princeton University Press, 2004.

Hammel, Paul. "Nebraskans Vote Overwhelmingly to Restore the Death Penalty." Omaha World Herald, November 9, 2016.

Hart, Gary, and William Shore. "Corporate Spending on State and Local Referendums: First National Bank of Boston v. Bellotti." Case Western Reserve Law Review 29, no. 4 (1979): 808-29.

Hartman, Stan. "Last Resort Remedy." Oregonian, October 10, 1978, B6.

Harvey, Joseph. "SJC Rules Death Penalty Is Illegal." Boston Globe, October 28, 1980. http:// www.nodp.org/ma/stacks/globe_102880.html.

Hauserman, Julie. "Panel Acts to Protect Death Penalty." St. Petersburg Times, March 4, 1998, $5 \mathrm{~B}$.

Herman, Edith. "Con-Con Votes to Retain Death Penalty." Chicago Tribune, June 3, 1970, 10.

Hough, Mike. "Populism and Punitive Penal Policy." CJM, 2002. https://www.crimeandjustice.org. uk/sites/crimeandjustice.org.uk/files/09627250208553483.pdf.

Johnson, Robert. "Reflections on the Death Penalty: Human Rights, Human Dignity, and Dehumanization in the Death House." Seattle Journal for Social Justice 13 (2004): 583-98. http:// digitalcommons.law.seattleu.edu/cgi/viewcontent.cgi?article $=1754 \&$ context $=$ sjsj.

Jones, Richard. "Death Penalty Vote Pushed Back." Milwaukee Journal Sentinel, May 5, 1995, B5.

Kateb, George. The Inner Ocean: Individualism and Democratic Culture. Ithaca, NY: Cornell University Press, 1994.

- Human Dignity. Cambridge, MA: Harvard University Press, 2011.

Kenney, Charles. "Most at Hearing Oppose Death Penalty." Boston Globe, March 23, 1982, 20.

Kilian, Michael. "Legislative Briefs." Chicago Tribune, June 14, 1969a, N4.

—_. "Legislators Calculate Move to Preserve Death Penalty." Chicago Tribune, June 15, 1969b, 11.

Kleiman, Carol. "The Political Migrant Worker." Chicago Tribune, March 14, 1971, E11.

Kouser, Thad, and Matthew D. McCubbins. "Social Choice, Crypto-Initiatives, and Policymaking by Direct Democracy." Southern California Law Review 78, no. 4 (2005): 949-84.

Kramer, Larry D. "The Interest of the Man: James Madison, Popular Constitutionalism, and the Theory of Deliberative Democracy." Valparaiso University Law Review 41 (2006): 697-754.

Kumar, Anita. "Push Is on to Start Pre-K Plan Early." St. Petersburg Times, November 5, 2002, $5 \mathrm{~B}$.

Leland, Timothy. "Now House Votes Death Penalty Study." Boston Globe, September 7, 1967, 6.

Lockman, Norm. "King, Dukakis on Crime: Rhetoric Is on the Rise." Boston Globe, August 29, 1982, 1.

Los Angeles Times "California Death Penalty Repeal, Proposition 34, Rejected." November 7, 2012. http://latimesblogs.latimes.com/california-politics/2012/11/proposition-34-californiadeath-penalty.html.

Magleby, David. Direct Legislation: Voting on Ballot Propositions in the United States. Baltimore, MD: Johns Hopkins University Press, 1984.

—. "Direct Legislation in the American States." In Referendums Around the World: The Growing Use of Direct Democracy, edited by David Butler and Austin Ranney, 218-57. Washington, DC: AEI Press, 1994.

Maiman, Bruce. "Fiscal Conservatives Should Oppose Death Penalty." Sacramento Bee, October 30, 2012, A11.

McDonnell, Patrick J. "State's Diversity Doesn't Reach Voting Booth." Los Angeles Times, November 10, 1994. http://articles.latimes.com/1994-11-10/news/mn-61019_1_diverse-state. 
Meisel, Josh. "Why I Will Vote No on California's Death Penalty Initiatives." Social Justice Blog, October 31, 2016. http://www.socialjusticejournal.org/2016/10/.

Michelson, A. A. "Death Penalty is a Deterrent ... to House Action." Boston Globe, August 26, 1967, 7.

Mitchell, Paula. "California's Death Penalty: A Year in Review." Verdict, November 13, 2013. https://verdict.justia.com/2013/11/18/californias-death-penalty-year-review.

Morning Oregonian "Governor Casts Noose from State." Morning Oregonian, November 24, 1911a, 1.

. "Governor West Appeals for Better Laws." Morning Oregonian, January 11, 1911b, 8.

. "People Approve Death Penalty-Four Opportunities to Abolish it by Popular Vote Slip By." Morning Oregonian, November 27, 1911c, 8.

. "Sentiment and Criminal Laws." Morning Oregonian, December 11, 1911d, 10

. "To Hang or Not to Hang." Morning Oregonian, December 23, 1911e, 8.

. "Why Not Protect Prison Society?" Morning Oregonian, December 26, 1911f, 8.

. "Death Sentence May Go-Initiative Bill Against Capital Punishment to Be Attempted."

Morning Oregonian, June 7, 1912a, 12.

. "The Law and the Poor Man." Morning Oregonian, February 13, 1912b, 8.

. "House for Electrocution." Morning Oregonian, January 18, 1913, 5

. "Ballot Measures Are in Conflict." Morning Oregonian, November 30, 1914a, 9.

. "Ballot Title Is Ready-Attorney General Designated Three Initiative Measures." Morning Oregonian, July 7, 1914b, 5.

. "Lawyers See Loophole-Others Express Opinion That Anti-Noose Act Errs." Morning Oregonian, October 22, 1914c, 4.

_. "Misrepresented Perhaps?" Morning Oregonian, October 21, 1914d, 10.

—_. "No More Hangings, Verdict of Voters." Morning Oregonian, December 1, 1914e, 6.

"Capital Punishment Bill Is Introduced." Morning Oregonian, January 31, 1919a, 7.

"Slayer Says Law Invited His Crime." Morning Oregonian, October. 22, 1919b, 1.

"Day's Events in Legislature." Morning Oregonian, January 15, 1920a, 1.

"Death Penalty Is Modified." Morning Oregonian, January 14, 1920b, 6.

Nyhan, David. "The Irish Are Making it (and Especially in Mass.)." Boston Globe, March 15, 1981, 67.

Ogletree, Charles, and Austin Sarat. Life Without Parole: America's New Death Penalty. New York: New York University Press, 2012.

O’Neill, Gerard. "Anti-Death Chair Bill Debated.” Boston Globe, April 10, 1969, 34.

Oregonian "Death Penalty Measure Regressive." Oregonian, October 26, 1978.

Ota, Alan. "Death Penalty Debated by Inmates, Prosecutor." Oregonian, October 1, 1978, B5.

Owens, Tess. "Capital Punishment: Voters in California, Nebraska and Oklahoma Choose to Preserve and Strengthen the Death Penalty." Vice News, November 9, 2016. https://news.vice. $\mathrm{com} /$ story/death-penalty-proponents-win-in-california-oklahoma-and-nebraska.

Ozella, Michael. "Audacity of the Court." Boston Globe, January 4, 1981, A6.

Padilla, Alex. "Official Voter Information Guide." 2016. http://vig.cdn.sos.ca.gov/2016/general/en/ pdf/complete-vig.pdf.

—. "Proposition 062-Death Penalty Initiative Statute." Cal-Access. n.d. http://cal-access.sos. ca.gov/Campaign/Measures/Detail.aspx?id=1381268\&session $=2015$.

Piott, Steven L. The Origins of the Initiative and Referendum in America. Columbia, MO: University of Missouri Press, 2003.

Post, Robert. "Democracy and Equality." Law, Culture, and the Humanities 1 (2005): 142-74.

Prescott Weekly Journal-Miner "Governor Hunt's Great Service." Prescott Weekly Journal-Miner, May 14, 1913a, 7.

—. "Murderers Get a New Lease for Life." Prescott Weekly Journal-Miner, April 16, 1913b, 5.

Price, Charles M. "Signing for Fun and Profit: The Business of Gathering Petition Signatures." California Journal 23, no. 11 (1992): 545-48. 
Puri, Prateek. "Propositions 62, 66 Take Opposing Approaches to California's Death Penalty." Daily Bruin, November 2, 2016. http://dailybruin.com/2016/11/02/propositions-62-66-takeopposing-approaches-to-californias-death-penalty/.

Ray, Richard. "New Death Ban Study Proposed." Boston Globe, February 15, 1967, 1.

Reeves, Breanna. "Conflicting Death Penalty Ballot Measures to Appear in Upcoming Election." University Wire, November 2, 2016.

Reyes, Rebeca. "Death Penalty Proposition in the California Ballot." University Wire, November 2, 2016.

Richardson, Bill. "I Carried Out the Death Penalty as a Governor. I Hope Others Put It to Rest." Washington Post, June 13, 2016. https://www.washingtonpost.com/posteverything/wp/2017/06/ 13/_trashed-2/?utm_term $=.7 \mathrm{e} 57 \mathrm{~d} 4587 \mathrm{e} 1 \mathrm{a}$.

Robinson, Walter. "The Most Polarizing Issue." Boston Globe, October 13, 1982, 1.

Sacramento Bee "End the Death Penalty: Yes on Propostion 24. Editorial." Sacramento Bee, September 14, 2012, A14.

Sanders, Jim. "Bill to Ban Death Penalty Is Shelved." Sacramento Bee, August 26, 2011, A3.

Sanburn, Josh. "The Future of the Death Penalty Will Be Decided in These 3 States." Time, November 8, 2016. http://time.com/4561649/death-penalty-referendum-california-nebraska/.

Sarat, Austin, Robert Kermes, Haley Cambra, Adelyn Curran, Margaret Kiley, and Keshav Pant. "The Rhetoric of Abolition: Continuity and Change in the Struggle Against America's Death Penalty." Journal of Criminal Law and Criminology 107 (2017): 757-80.

Scheingold, Stuart. The Politics of Law and Order: Street Crime and Public Policy. New York: Longman, 1984.

Schrag, Peter. Paradise Lost: California's Experience, America's Future. Berkeley, CA: University of California Press, 1998.

Shafer, Scott. "Death Penalty Propositions Divide Voters." KQED News, September 22, 2016. https://ww2.kqed.org/news/2016/09/22/death-penalty-propositions-divide-voters/.

Simon, Jonathan. Governing Through Crime: How the War on Crime Transformed American Democracy and Created a Culture of Fear. New York: Oxford University Press, 2009.

Skelton, George. "Capitol Journal: Dump the Death Penalty." Los Angeles Times, September 13, 2012, A2.

Smith, Daniel, and Caroline Tolbert. "Direct Democracy, Public Opinion, and Candidate Choice." Public Opinion Quarterly 74, no. 1 (2010): 85-108.

Stanton, Sam. "Death Penalty Foes Seek to Put Push for Abolition on Ballot." Sacramento Bee, August 30, 2011, A3.

Steiker, Carol, and Jordan Steiker. "The More We Confront the Death Penalty, the Less We Like It." Los Angeles Times, November 23, 2016, A13.

St. John, Paige, and Maloy Moore. "There Are 749 Inmates Awaiting Execution on California's Death Row. Los Angeles Times, December 20, 2016. http://www.latimes.com/projects/la-medeath-row/.

Stoddard, Martha. "Ricketts Gives Another Big Boost to Push for Executions-Second $\$ 100,000$ Means Governor Funding Nearly Third of Petition Drive." Omaha World Herald, August 1, 2015, 1A.

St. Petersburg Times "No on Amendment 1." St. Petersburg Times, October 12, 2002, 2D.

Strong, James. "CFL Asks Rejection of New Constitution." Chicago Tribune, November 11, 1970a, 23.

_. "Chicago Labor Group Balks at Opposing New Constitution." Chicago Tribune, September 30, $1970 \mathrm{~b}, 16$.

Sunstein, Cass. "Justice Breyer's Democratic Pragmatism." Yale Law Journal 115 (2006): 1719-43.

Toobin, Jeffrey. "The Strange Case of the American Death Penalty." New Yorker, December 21, 2016. http://www.newyorker.com/news/daily-comment/the-strange-case-of-the-americandeath-penalty.

Tulsa World "State Question 776: Oklahoma Voters Reaffirmed Their Support for Capital Punishment." Tulsa World, November 8, 2016. http://www.tulsaworld.com/news/elections/state- 
question-oklahoma-voters-reaffirmed-their-support-of-capital-punishment/article_fa166d3bc406-54c6-b77a-39afc1fdc0c0.html.

Ulloa, Jazmine. "Tech Execs Back Repeal of Death Penalty." Los Angeles Times, October 15, 2016, B1.

Walters, Steven. "Most in State Want Return of Death Penalty: Senator Says Reinstatement Close to Passing." Milwaukee Journal Sentinel, April 20, 1995, B1.

Wasson, David. "Ballot Measures Bonanza Reaches 9." Tampa Tribune, August 2, 2002, 1.

Whitman, James. Harsh Justice: Criminal Punishment and the Widening Divide Between America and Europe. New York: Oxford University Press, 2003.

Wisconsin Historical Society "The Death Penalty in Wisconsin." n.d. https://www.wisconsinhistory.org/Records/Article/CS2816.

Wolfe, Sheila. "Democrats End Con-Con Study." Chicago Tribune, November 26, 1970, A3.

Woodford, Jeanne. "Yes on 34 Takes the Lead." Huffington Post, November 3, 2012, http://www. huffingtonpost.com/jeanne-woodford/prop-34-death-penalty_b_2067617.html.

Zimring, Franklin E. "Endgame for Death Penalty in California; CAPITAL PUNISHMENT Prop. 34's Narrow Loss a Big Step Toward Abolition of Execution." San Francisco Chronicle, December 8, 2012. https://deathpenaltyinfo.org/how-death-penalty-might-be-ended-california.

Zimring, Franklin E., and Gordon Hawkins. Capital Punishment and the American Agenda. Cambridge: Cambridge University Press, 1986.

Zisk, Betty. Money, Media, and the Grass Roots. Newbury Park, CA: Sage, 1987.

\section{CASES CITED}

Armstrong v. Harris, 773 So. $2 d 7$ (Fla. 2000).

Commonwealth v. O'Neal Part I, 367 Mass. 440 (1975).

Commonwealth v. O’Neal Part II, 369 Mass. 242 (1975).

District Attorney for the Suffolk District v. Watson, 381 Mass. 648 (1981).

First National Bank of Boston v. Bellotti, 435 U.S. 765 (1978).

Furman v. Georgia, 408 U.S. 238 (1972).

Gregg v. Georgia, 428 U.S. 153 (1976).

In re Proportionality Review Project, 735 A.2d 528 (N.J. 1999).

Jones v. Chappell, 31 F. Supp. 3d 1050 (C.D. Cal. 2014).

Jones v. Davis, 806 F.3d 538 (2015).

Jones v. State, 701 So. $2 d 76$ (Fla. 1997).

Meyer v. Grant, 486 U.S. 414 (1988).

Rudolph v. Alabama, 152 So. 2d 662, cert. denied 375 U.S. 889 (1963).

Trop v. Dulles, 356 U.S. 86 (1958).

Witherspoon v. Illinois, 391 U.S. 510 (1968). 